\title{
OPTIMALISASI PEMANFAATAN HIJAUAN PAKAN TERNAK (HPT) LOKAL MENDUKUNG PENGEMBANGAN USAHA TERNAK SAPI
}

\author{
Ni Luh Gede Budiari dan I Nyoman Suyasa \\ Balai Pengkajian Teknologi Pertanian (BPTP) Bali \\ Jl. By Pass Ngurah Rai, Pesanggaran, Bali \\ Email: budiariluhde@yahoo.co.id
}

\begin{abstract}
ABSTRAK
Pakan merupakan salah satu faktor yang dapat meningkatkan produktivitas ternak selain faktor genetik. Produktivitas ternak sapi dapat dinaikkan apabila pakan yang diberikan memenuhi kebutuhan ternak. Sebuah kajian telah dilaksanakan di Desa Antapan dan Bangli, Kecamatan Baturiti, Kabupaten Tabanan, Desa Tukad Sumaga, Kecamatan Gerokgak dan Desa Pancasari, Kecamatan Sukasada, Kabupaten Buleleng, dan di Desa Nusa Penida, Kecamatan Nusa Penida, Kabupaten Klungkung dari tahun 2017 sampai Tahun 2018. Hijauan spesifik lokasi di Kabupaten Tabanan, Buleleng dan Klungkung sangat beragam jenisnya dan tumbuhnya tergantung dari kondisi masing-masing wilayah. Kandungan gizi dari masing-masing tanaman lokal cukup tinggi tergantung dari jenis tanamannya. Tanaman lokal memiliki daya adaptasi yang tinggi pada tempatnya dan dapat dijadikan pakan alternatif pengganti rumput pada saat musim kemarau
\end{abstract}

Kata kunci: hijauan spesifik lokasi, kwalitas nutrisi, pemanfaatan hijauan

\section{PENDAHULUAN}

Ternak sapi merupakan salah satu indikator dalam pencapaian swasembada daging tingkat nasional. Untuk mencapai swasembada daging produktivitas dan populasi ternak harus ditingkatkan. Oleh karena itu pengembangan sapi potong sangat dibutuhkan dalam memenuhi permintaan daging yang semakin hari semakin meningkat. Peningkatan kebutuhan daging akan terus terjadi, mengingat semakin meningkatnya laju pertumbuhan dan pendapatan penduduk. Potensi ini merupakan peluang sekaligus tantangan bagi peternak untuk mengembangkan usaha ternak sapinya. Kenyataan di lapangan pengembangan usaha ternak sapi, khususnya di Bali terkendala dengan sempitnya lahan akibat terjadinya alih fungsi lahan, terutama perubahan lahan sawah, tegalan menjadi kawasan pemukiman menyebabkan menurunkan produksi hijauan, produksi jerami untuk pakan, atau pun hasil ikutannya seperti dedak padi. Yusdja dan Ilham (2006) menyatakan penurunan produksi pakan akan mempengaruhi daya dukung ternak untuk menyediakan pakan bahkan menyebabkan penurunan populasi karena petani merasakan kesulitan untuk mengembangkan ternak, padahal keberlanjutan program pengembangan ternak pada suatu wilayah ditentukan oleh ketersediaan pakan.

Pakan merupakan salah satu faktor yang dapat meningkatkan produktivitas ternak selain faktor genetik. Produktivitas ternak sapi dapat dinaikan apabila pakan yang diberikan memenuhi kebutuhan ternak. Oleh karena itu jenis pakan yang diberikan harus bermutu baik dan dalam jumlah yang cukup. Mariyono dan Romjali (2007) menyatakan produktivitas ternak sangat dipengaruhi oleh kualitas dan kuantitas pakan. As -Syakur e $t$ al. (2011) melaporkan produktivitas ternak sapi akan terjaga apabila pakan yang diberikan kualitas dan kuantitasnya stabil. Lebih lanjut dijelaskan bahwa tanaman pakan merupakan salah satu pendukung peningkatan produktivitas ternak, oleh karena itu ketersediaan dan kualitasnya harus tetap terjaga agar dapat memenuhi kebutuhan ternak.

Pengembangan hijauan pakan ternak (HPT) spesifik lokasi dan pemanfaatan limbah pertanian merupakan salah satu pendukung dalam pengembangan sapi potong yang secara langsung akan membantu memecahkan permasalahan dalam penyediaan pakan. Umumnya peternak masih sangat ketergantungan pada alam dalam penyediaan pakan ternaknya. Pada musim kemarau peternak hanya memberikan pakan seadanya tanpa memperhatikan kualitas, kuantitas dan efisiensi pemberiannya. Gunawan et al. (2003) melaporkan bahwa sapi bali yang diberi pakan rumput lapangan saja hanya memberikan pertambahan berat badan sebesar 100-200 g/ekor/ hari. Budiari et al. (2014) melaporkan pertumbuhan sapi pembesaran di tingkat petani dengan pakan rumput lapang, untuk mencapai bobot badan 200 $\mathrm{kg}$ dari $86 \mathrm{~kg}$ membutuhkan waktu selama 1 tahun, dengan pertambahan berat badan $0,32 \mathrm{~kg} / \mathrm{hari}$. Hal ini menyebabkan menurunnya populasi sapi bali, karena menurunnya keuntungan berusahatani ternak sapi sebagai akibat penurunan produktivitas (Yasa, 2016). Disamping pengaruhnya yang besar terhadap produktivitas ternak, pakan juga merupakan biaya 
produksi yang cukup besar dalam usaha ternak.

Hijauan pakan ternak lokal dan limbah pertanian belum dimanfaatkan secara optimal, dan sebagian besar digunakan sebagai bahan bakar, pupuk organik dan bahan baku industri. Oleh karena itu Balitbangtan mengembangkan teknologi peternakan spesifik lokasi yang memanfaatkan potensi sumberdaya lokal. Pemanfaatan limbah pertanian dan mengembangkan HPT lokal sebagai pakan ternak diharapkan mampu mengurangi ketergantungan peternak terhadap pakan komersial yang harganya mahal. HPT lokal memiliki daya adaptasi pertumbuhan yang efektif dengan lingkungan hidupnya sehingga produksinya dapat terjaga sepanjang tahun. Sedangkan limbah pertanian yang dulunya tidak berdayaguna dengan sentuhan teknologi dapat dimanfaatkan sebagai pakan yang mengandung gizi lebih baik.

\section{MATERI DAN METODE}

\section{Lokasi dan waktu}

Kajian ini dilaksanakan di Desa Antapan dan Bangli, Kecamatan Baturiti, Kabupaten Tabanan, Desa Tukad Sumaga, Kecamatan Gerokgak dan Desa Pancasari, Kecamatan Sukasada, Kabupaten Buleleng, Desa Nusa Penida, Kecamatan Nusa Penida, Kabupaten Klungkung dari tahun 2017 sampai Tahun 2018.

\section{Bahan dan Alat}

Bahan yang digunakan dalam kajian ini aneka jenis hijauan spesifik lokasi. Alat-alat yang dipergunakan timbangan digital, tali dan sabit.

\section{Prosedur Penelitian}

Kegiatan diawali dengan survei ke masing-masing peternak mengenai pakan lokal yang biasa diberikan pada ternaknya pada saat musim kemarau. Setelah diperoleh jenis hijauan yang diberikan, selanjutnya dilakukan pengumpulan hujauan pakan lokal dari masing-masing wilayah. Hijauan pakan lokal selanjutnya dipotong kecil-kecil $(5 \mathrm{~cm})$ kemudian dijemur di bawah sinar matahari selama 1 hari, kemudian dimasukan oven suhu $60^{\circ} \mathrm{C}$, kemudian dikirim ke Laboratorium Nutrisi dan Pakan Ternak, Grati untuk mengetahui kandungan gizinya.

\section{Analisis data}

Data yang dikumpulkan dianalisis deskriptif untuk mengetahui kandungan gizi dari masing-masing sampel hijauan lokal dilakukan analisis proksimat di Laboratorium Nutrisi Pakan Ternak, Loka Penelitian Sapi Potong, Grati.

\section{HASIL DAN PEMBAHASAN}

Pulau Bali merupakan daerah pariwisata, sehingga sebagian besar wilayahnya digunakan untuk mendukung fasilitas pariwisata tersebut, seperti pembangunan hotel, restoran dan perumahan. Lahan-lahan untuk usaha pertanian dan peternakan semakin hari semakin sempit, sehingga usaha pengembangan ternak sapi akan terkendala dengan lahan dan pengembangan hijauan pakan. Usaha untuk membudidayakan hijauan unggul jarang dilakukan oleh peternak karena peternak sebagian besar menggantungkan kebutuhan pakan ternaknya pada alam. Disamping itu juga adanya anggapan bahwa penanaman hijauan pakan secara ekonomi tidak menguntungkan sehingga pertanian yang mengkhusus untuk memproduksi tanaman pakan sangat jarang (As- Syakur et al., 2011).

Untuk menjaga kelestarian dan populasi ternak sapi Bali usaha yang dilakukan adalah mengoptimalkan pemanfaatan pakan lokal yang spesifik lokasi. Masing-masing wilayah kabupaten di Bali memiliki tanaman pakan yang spesifik yang dimanfaatkan oleh peternak setempat untuk pakan ternaknya. Jenis dan kandungan gizi hijauan pakan lokal di Kabupaten Tabanan dapat dilihat pada Tabel 1, 2, dan 3. Data Kabupaten Buleleng dapat dilihat pada Tabel 4 dan 5, sedangkan untuk Kabupaten Klungkung (daerah Nusa Penida) dapat dilihat pada Tabel 6.

Pemanfaatan pakan lokal biasanya dilakukan pada saat musim kemarau dimana produksi rumput telah menurun. Hijauan lokal ini biasanya produksinya sepanjang tahun sehingga pemanfaatannya biasa dilakukan pada saat musim kemarau. Untuk mengetahui kandungan gizi dari masing-masing hijauan pakan lokal, dilakukan analisis proksimat di Laboratorium pakan ternak, Lolit Sapi Potong, Grati.

\section{Hijauan Pakan Lokal Kabupaten Tabanan}

Hijauan pakan lokal untuk wilayah Kabupaten Tabanan sebagian besar berupa rumput-rumputan yang tumbuhnya di pinggir sungai dan tegalan. Tabel 1, 2, dan 3 menunjukkan jenis hijauan dan kandungan gizi pakan lokal di Kabupaten Tabanan. Dilihat dari kandungan gizi dari masing-masing hijauan lokal tersebut kandungan proteinnya cukup tinggi hampir sama dengan kandungan protein rumput unggul. Pakan hijauan merupakan pakan utama ternak ruminansia. Komposisinya mencapai 73,8-94,0\% dari total penggunaan pakan, selebihnya berasal dari pakan konsentrat (Jacoeb dan Munandar, 1991). Dengan adanya kombinasi dari berbagai jenis hijauan yang diberikan maka kebutuhan gizi dari ternak sapi akan tetap terpenuhi sehingga pertumbuhannya meningkat. Zulbardi et al. (2000) melaporkan bahwa 
Tabel 1. Jenis hijauan lokal dan kandungan gizi hijauan pakan ternak di Desa Antapan, Kecamatan Baturiti, Kabupaten Tabanan

\begin{tabular}{lrrrrrrrrr}
\hline \multirow{2}{*}{\multicolumn{1}{c}{ Bahan Pakan }} & \multirow{2}{*}{ Kadar Air 135 c c } & \multicolumn{1}{c}{ Hasil Analisis Proksimat (\%) } \\
\cline { 3 - 11 } & & \multicolumn{1}{c}{ DK } & \multicolumn{1}{c}{ LK } & \multicolumn{1}{c}{ SK } & \multicolumn{1}{c}{ Abu } & BETN & TDN & Ca \\
\hline Padang batur & 8 & 92 & 2,86 & 2,54 & 33,64 & 8,57 & 52,39 & 51,34 & 0,42 \\
Padang getah & 7,05 & 92,95 & 7,06 & 5,16 & 20,95 & 13,22 & 53,61 & 60,99 & 0,72 \\
Paku lengis & 7,3 & 92,7 & 9,91 & 2,31 & 18,9 & 21,13 & 47,75 & 54,81 & 0,87 \\
Samblung & 6,83 & 93,17 & 17,17 & 3,17 & 30,34 & 16,1 & 33,22 & 49,94 & 1,01 \\
Muluk-muluk & 7,21 & 92,79 & 13 & 1,12 & 23,63 & 30,12 & 32,13 & 48,84 & 2,41 \\
Mentek-mentek kayu & 6,51 & 93,49 & 17,11 & 1,42 & 28,74 & 25,66 & 27,07 & 48,09 & 3,1 \\
Mentek-mentek biru & 6,58 & 93,42 & 12,91 & 2,33 & 21,7 & 16,32 & 46,73 & 57,02 & 1,06 \\
\hline
\end{tabular}

Keterangan: Hasil analisis Laboratorium Nutrisi dan Pakan Ternak, Grati Jawa Timur

Tabel 2. Jenis hijauan lokal dan kandungan gizi hijauan pakan ternak di Desa Antapan, Kecamatan Baturiti, Kabupaten Tabanan

\begin{tabular}{lcrrrrrrrr}
\hline \multirow{2}{*}{ Bahan Pakan } & \multirow{2}{*}{ Kadar Air 135 c c } & \multicolumn{7}{c}{ Hasil Analisis Proksimat (\%) } \\
\cline { 3 - 10 } Daun Penyangkulan & 7,14 & 92,87 & PK & LK & SK & Abu & BETN & TDN & Ca \\
Ketoktok & 2,96 & 97,04 & 6,9 & 2,67 & 21,59 & 14,33 & 51,6 & 56,68 & 0,9 \\
Mentek-mentek hijau & 6,22 & 93,78 & 10,81 & 2,41 & 16,39 & 22,77 & 47,61 & 57,42 & 1,96 \\
Buyung-buyung & 6,64 & 93,36 & 17,06 & 4,13 & 15,54 & 15,17 & 48,1 & 68,17 & 1,26 \\
Padang damuh & 2 & 98 & 11,12 & 2,73 & 12,84 & 34,45 & 38,86 & 58,69 & 0,49 \\
Bajang-bajang & 7,05 & 92,95 & 16,49 & 2,52 & 19,98 & 13,82 & 47,19 & 62,64 & 0,77 \\
Besi ambuh & 7,66 & 92,34 & 20,27 & 1,9 & 26,07 & 21,12 & 30,64 & 55,14 & 2,03 \\
\hline
\end{tabular}

Keterangan: Hasil analisis Laboratorium Nutrisi dan Pakan Ternak, Grati Jawa Timur

Tabel 3. Jenis hijauan lokal dan kandungan gizi hijauan pakan ternak di Desa Bangli, Kecamatan Baturiti, Kabupaten Tabanan

\begin{tabular}{lrrrrr}
\hline Nama Bahan & BK (\%) & PK (\%) & LK (\%) & SK (\%) & TDN (\%) \\
\hline Pucuk & 91,25 & 23,57 & 3,47 & 16,62 & 54,28 \\
Lemutu & 93,43 & 13,54 & 4,21 & 22,16 & 47,99 \\
Sayur Hijau & 90,39 & 23,29 & 2,28 & 13,64 & 57,19 \\
Lengkuas & 93,19 & 11,01 & 4,32 & 25,26 & 45,97 \\
Pepaya & 89,37 & 7,18 & 5,09 & 23,56 & 58,36 \\
Kunyit & 92,66 & 10,23 & 6,48 & 20,87 & 47,88 \\
Kebenben & 91,89 & 18,21 & 3,47 & 16,85 & 52,32 \\
Bongkot & 92,16 & 28,10 & 3,21 & 20,20 & 59,61 \\
Endong & 93,14 & 11,04 & 3,44 & 23,52 & 44,38 \\
R. tiying & 92,35 & 15,89 & 4,16 & 24,16 & 57,47 \\
Paku sayur & 91,62 & 17,79 & 4,30 & 15,13 & 51,15 \\
\hline
\end{tabular}

Keterangan: Hasil analisis Laboratorium Nutrisi dan Pakan Ternak, Grati Jawa Timur

sapi penggemukan membutuhkan protein kasar dalam ransumnya sebanyak $12 \%$, oleh karena itu pemberian pakan pada ternak sapi perlu dikombinasikan antara rumput dengan legum.

\section{Hijauan Pakan Lokal Kabupaten Buleleng}

Di Kecamatan Gerokgak, Kabupaten Buleleng pakan lokal yang diberikan pada saat musim kemarau dan kandungan gizi dari pakan tersebut tertera pada Tabel 4. Pada saat musim kemarau peternak di wilayah Kecamatan Gerokgak akan memberikan pakan sapinya hay dan hijauan yang kandungan gizinya cukup tinggi, sehingga pada saat musim kemarau pertumbuhan sapi di wilayah kabupaten Buleleng lebih tinggi daripada saat musim hujan. Hal ini disebabkan pada saat musim hujan peternak sebagian besar ternaknya diberikan pakan rumput sedangkan pada musim kemarau sebagian ternaknya diberikan pakan dari hijauan yang kandungan proteinnya lebih tinggi dari rumput. Mariyono dan Romjali. (2007) melaporkan bahwa produktivitas ternak sangat dipengaruhi oleh kualitas dan kuantitas pakan.

Kualitas nutrisi bahan pakan merupakan faktor utama dalam memilih dan menggunakan bahan makanan tersebut sebagai sumber zat makanan untuk memenuhi kebutuhan hidup pokok dan produksinya, kualitas nutrisi bahan pakan terdiri atas komposisi nilai gizi, serat, energi, dan aplikasinya pada nilai palatabilitas dan daya cernanya (Sofyan et al., 2000). Rhodes et al. (2003) menyatakan salah satu faktor yang mempengaruhi penampilan reproduksi pada sapi potong adalah kualitas pakan yang diberikan. Secara umum kualitas hijauan didaerah tropis lebih rendah daripada di daerah subtropis karena kandungan $\mathrm{N}$ yang rendah dan kandungan serat kasar tinggi (Sumarsono et al., 2009).

Tabel 4. Jenis hijauan lokal dan kandungan gizi hijauan pakan ternak di Desa Tukad Sumaga, Kecamatan Gerokgak, Kabupaten Buleleng

\begin{tabular}{lccccccc}
\hline Nama Bahan & $\begin{array}{c}\text { Berat } \\
\text { segar } \\
\text { (gr) }\end{array}$ & $\begin{array}{c}\text { Berat } \\
\text { oven } \\
\text { (gr) }\end{array}$ & $\begin{array}{c}\text { \% } \\
\text { Bahan }\end{array}$ & BK\% & ABU \% & SK \% & PK\% \\
\hline Sona keling & 735 & 369 & 49,80 & 86,26 & 7,07 & 24,95 & 17,66 \\
Daun Mete & 745 & 435 & 41,61 & 94,03 & 4,67 & 23,32 & 12,38 \\
$\begin{array}{l}\text { Daun Intaran } \\
\text { Daun Kesa- }\end{array}$ & 800 & 257 & 67,88 & 91,69 & 8,03 & 26,49 & 19,85 \\
mbi & 705 & 464 & 34,18 & 93,84 & 7,95 & 33,48 & 14,22 \\
\hline
\end{tabular}

Keterangan: Hasil analisis Laboratorium Nutrisi dan Pakan Ternak, Grati Jawa Timur

Tabel 5 menunjukkan hijauan pakan yang hidupnya di Danau Buyan dan Tamblingan, dimana hijauan pakan ini sebagian besar dimanfaatkan oleh peternak untuk pakan babi dan itik. Dilihat 
Tabel 5. Jenis hijauan lokal dan kandungan gizi hijauan pakan ternak di Desa Pancasari, Kecamatan Sukasada, Kabupaten Buleleng

\begin{tabular}{|c|c|c|c|c|c|c|c|c|c|c|}
\hline \multirow[b]{2}{*}{ Jenis Hijauan } & \multirow[b]{2}{*}{ Kadar Air 135 c } & \multicolumn{9}{|c|}{ Hasil Analisis Proksimat (\%) } \\
\hline & & $\mathrm{DM}$ & $\mathrm{PK}$ & LK & SK & $\mathrm{ABU}$ & BETN & TDN & $\begin{array}{c}\text { Energi To- } \\
\text { tal (Kcal/ } \\
\text { kg) }\end{array}$ & $\mathrm{Ca}$ \\
\hline Akar Ganggang & 11,68 & 88,32 & 5,12 & 0,79 & 27,22 & 8,14 & 58,74 & 47,43 & 4038,32 & 0,99 \\
\hline Eceng Gondok & 8,69 & 91,31 & 8,16 & 1,45 & 19,93 & 13,93 & 56,53 & 52,25 & 3837,28 & 2,05 \\
\hline Batang Ganggang & 6,24 & 93,76 & 3,85 & 1,28 & 10,61 & 5,81 & 78,44 & 47,06 & 4011,54 & 1,32 \\
\hline Kayu apu & 10,76 & 89,24 & 2,86 & 0,51 & 30,74 & 9,64 & 56,26 & 44,23 & 3951,6 & 1,06 \\
\hline Akar eceng gondok & 9,87 & 90,13 & 9,23 & 1,27 & 23,26 & 13,16 & 53,09 & 51,64 & 3901,76 & 0,99 \\
\hline Akar kayu apu & 10,74 & 89,26 & 5,06 & 1,98 & 32,76 & 20,6 & 39,59 & 41,07 & 3642,6 & 0,93 \\
\hline
\end{tabular}

Keterangan: Hasil analisis Laboratorium Nutrisi dan Pakan Ternak, Grati Jawa Timur.

Tabel 6. Jenis hijauan lokal dan kandungan gizi hijauan pakan ternak di Desa Nusa Penida, Kecamatan Nusa Penida, Kabupaten Klungkung

\begin{tabular}{|c|c|c|c|c|c|c|c|c|c|}
\hline \multirow{2}{*}{ Jenis Hijauan } & \multicolumn{8}{|c|}{ Analisis Proksimat (Dalam \%) } & \multirow{2}{*}{$\begin{array}{l}\text { Total Energi } \\
\text { (Kcal/Kg) }\end{array}$} \\
\hline & Kadar Air & $\mathrm{BK}$ & $\mathrm{PK}$ & LK & SK & K. Abu & BETN & TDN & \\
\hline Beringin & 6,77 & 93,23 & 9,43 & 4,69 & 34,3 & 13,66 & 37,92 & 44,06 & 4020,3 \\
\hline Bentenu & 8,76 & 91,25 & 17,73 & 2,69 & 14,16 & 9,38 & 56,04 & 70,56 & 3749,9 \\
\hline Waru & 7,25 & 92,75 & 19,75 & 3,5 & 23,14 & 12,92 & 40,69 & 61,87 & 4006,7 \\
\hline Gamelina & 7,65 & 92,35 & 18,67 & 2,49 & 11,82 & 9,17 & 57,86 & 72,47 & 4220,4 \\
\hline Anggih & 8,94 & 91,06 & 16,33 & 3,69 & 19,02 & 8,55 & 52,41 & 68,08 & 4545,75 \\
\hline Bangsing & 8,83 & 91,17 & 7,72 & 2,56 & 32,79 & 14,21 & 42,72 & 47,68 & 3746 \\
\hline Gamal & 10,28 & 89,72 & 28,58 & 3,52 & 14,74 & 12,11 & 41,04 & 78,44 & 3931,4 \\
\hline Bunut & 7,49 & 92,51 & 11,75 & 4,78 & 32,18 & 11,42 & 39,87 & 48,98 & 3947 \\
\hline
\end{tabular}

Keterangan: Hasil analisis Laboratorium Nutrisi dan Pakan Ternak, Grati Jawa Timur

dari kandungan gizi dari hijauan yang tumbuh di Danau Buyan dan Tamblingan sangat rendah (Tabel 5) disamping itu karena palatabilitasnya rendah menyebabkan hijauan pakan ini kurang disukai oleh ternak sapi. Populasi yang tinggi dan produksinya melimpah menyebabkan hijauan ini banyak yang tidak dimanfaatkan dan menjadi limbah. Pertumbuhannya yang cepat menyebabkan hijauan ini menjadi gulma bagi Danau Buyan dan Tablingan karena dapat mengganggu keindahan danau dan menyebabkan pendangkalan danau. Oleh karena itu perlu adanya sentuhan teknologi yang dapat mengolah hijauan ini untuk dapat dimanfaatkan untuk pakan ternak sapi, terutama pada saat musim kemarau.

\section{Hijauan Pakan Lokal Kabupaten Klungkung}

Kepulauan Nusa Penida merupakan wilayah pengembangan pembibitan sapi Bali, yang lokasinya di Kabupaten Klungkung. Sebagai wilayah pusat pembibitan sapi bali maka kebutuhan pakan akan semakin banyak, sedangkan wilayah nusa penida adalah daerah beriklim kering dimana pada musim kemarau ketersediaan hijauan sangat kurang. Tidak seimbangnya produksi hijauan pada musim hujan dan musim kemarau menimbulkan kesulitan dalam penyediaan pakan hijauan secara baik (Sawen et al., 2003). Muryanto, et al. (1995) melaporkan bahwa peternakan rakyat dicirikan dengan permasalahan pakan terutama pada musim kemarau. Disamping itu banyak waktu yang dicurahkan peternak untuk mendapatkan rumput, terutama disebabkan jauhnya jarak antara lokasi petemak dengan tempat menyabit rumput. Kondisi ini dapat dijadikan indikasi bahwa sebagian besar peternak belum membudidayakan tanaman hijauan pakan ternak untuk kebutuhan ternak yang dipeliharanya.

Permasalahan pakan untuk wilayah Nusa Penida oleh berbagai instansi terkait telah diupayakan dengan penyediaan tanaman rumput yang mempunyai kualitas, daya saing, toleransi, dan efisiensi yang lebih baik. Disamping penyediaan pakan unggul pemanfaatan pakan spesifik lokasi perlu tetap dilestarikan. Jenis pakan dan kandungan gizi dari pakan spesifik lokasi Nusa Penida tertera pada Tabel 6. Pemanfaatan pakan lokal ini biasanya pada saat musim kemarau pada saat produksi rumput menurun. Jenis tanaman ini tumbuhnya besar-besar dan produksinya sangat banyak. Untuk kebutuhan pakan pada saat musim kemarau peternak mencampur pakan lokal dengan limbah pertanian yang telah dibuat hay.

Jenis hijauan lokal memiliki adaptasi yang lebih baik dari pakan unggul, disamping juga kandungan gizinya yang lebih tinggi. Dengan adanya teknologi pengawetan pakan, pakan lokal, gulma dan rumput yang berlebih pada saat musim hujan dapat disimpan dan dimanfaatkan secara optimal pada saat musim kemarau sehingga kebutuhan pakan untuk wilayah nusa penida akan tercukupi. 


\section{SIMPULAN}

Hijauan spesifik lokasi di Kabupaten Tabanan, Buleleng dan Klungkung sangat beragam jenisnya dan tumbuhnya tergantung dari kondisi masing-masing wilayah. Kandungan gizi dari masing-masing tanaman lokal cukup tinggi tergantung dari jenis tanamannya. Tanaman lokal memiliki daya adaptasi yang tinggi pada tempatnya dan dapat dijadikan pakan alternative pengganti rumput pada saat musim kemarau

\section{DAFTAR PUSTAKA}

As-Syakur. A.R., I.W.Suarna, I.W.Rusna, dan I.N.Dibia. (2011). Pemetaan Kesesuaian Iklim Tanaman Pakan Serta Kerentanannya Terhadap Perubahan Iklim Dengan Sistem Informasi Geografi (SIG) di Propinsi Bali. Pastura. Journal Of Tropical Forage Science. Jurnal Ilmu Tumbuhan Pakan Tropik. Himpunan Ilmuwan Tumbuhan Pakan Indonesia (HITPI). Vol 1 Agustus 2011. Hal 9-13.

Budiari, N.L.G., I.M. Raiyasa, dan I.P.A. Kertawirawan. 2014. Peningkatan Produktivitas Sapi Bali Dara Dengan Pemanfaatan Limbah Jagung Manis. Prosiding. Seminar Nasional. Pembangunan Nasional Berbasis Teknologi dan Sumberdaya Lokal. Kerjasama LPPM dengan Fakultas Pertanian, Universitas Muhammadiyah Jember.

Gunawan, A. Dickey, dan S. Lukman. 2003. Sapi Bali, Potensi Produktivitas dan Nilai Ekonomi. Penerbit Kanisius, Yogyakarta.

Jacoeb, T.N. dan S. Munandar. 1991. Petunjuk Teknis Pemeliharaan Sapi Potong. Ditjen Peternakan. Jakarta.

Mariyono dan E. Romjali. 2007. Petunjuk Teknis Teknologi Inovasi Pakan Murah Untuk Usaha Pembibitan Sapi Potong. Loka Penelitian Sapi Potong. Grati Pasuruan. Hal 1- 28.
Muryanto, U. Nuschati, Subiharta, W. Dirdjapratono, U. Kusnadi dan B.R Prawiradiputra. 1995. Introduksi Temak Kambing dan Hijauan Pakan Ternak pada Sistem Usahatani di Lahan Kering. Prosiding Pertemun Ilmih Komunikasi dan Penyaluran Hasil Penelitian. Buku II: 271-277. Sub Balai Penelitian Ternak Klepu. Semarang.

Sawen, D., O.Yoku, dan M. Junaidi. 2003. Kualitas silase rumput Irian (Sorghum Sp) dengan perlakuan penambahan dedak padi pada berbagai tingkat produksi bahan kering. Fakultas Peternakan Perikanan dan Ilmu Kelautan Universitas Negeri Papua, Manokwari, Papua.

Sofyan, L. A., L. Aboenawan, E. B. Laconi, A. Djamil, N. Ramli, M. Ridla, dan A.D. Lubis. 2000. Pengetahuan bahan makanan ternak. Lab. Ilmu dan Teknologi Pakan. Fakultas Peternakan IPB. Bogor.

Sumarsono, S., D. W. Anwar, dan S. Budiyanto. 2009. Penerapan Pupuk Organik untuk Perbaikan Penampilan dan Produksi Hijuan Rumput Gajah pada Tanah Masam. Seminar Nasional Kebangkitan Peternakan - Semarang, Fakultas Peternakan, Univesitas Diponogoro, Semarang.

Yasa I M R. IN Adijaya, N L G Budiari, P A Kertawirawan, N W Trisnawati, I N Sutresna, dan I P Sugiarta. 2016. Laporan Akhir Model Penggemukan Sapi Bali di Daerah Pengembangan Sayuran. Balai Pengkajian Teknologi Pertanian Bali. Denpasar. Yusdja Y dan N. Ilham. 2006. Arah Kebijakan Pembangunan Peternakan Rakyat. Analisis Kebijakan Pertanian 2 (2): 183 - 203.

Zulbardi M, Kuswandi, M. Martawidjaja, C. Thalib dan D.B. Wiyono. 2000. Daun Gliricidia Sebagai Sumber Protein Pada Sapi Potong. Prosiding Seminar Nasional Peternakan dan Veteriner. Bogor, 18-19 September 2000. Pusat Penelitian dan Pengembangan Peternakan. Bogor. Halm $233-241$. 